\title{
L-citrulline protects from kidney damage in type 1 diabetic mice
}

\author{
Maritza J. Romero ${ }^{1,2,3}$ *, Lin Yao ${ }^{1}$, Supriya Sridhar ${ }^{3}$,Anil Bhatta ${ }^{1}$, Huijuan Dou ${ }^{3}$, Ganesan Ramesh ${ }^{3,4}$, \\ Michael W. Brands ${ }^{5}$, David M. Pollock ${ }^{1,4}$, Ruth B. Caldwell ${ }^{3,6,78}$, Stephen D. Cederbaum ${ }^{9}$, C. Alvin Head ${ }^{2}$, \\ Zsolt Bagi ${ }^{3}$, Rudolf Lucas ${ }^{1,3,10}$ and Robert W. Caldwell ${ }^{1,5}$ \\ ${ }^{1}$ Department of Pharmacology and Toxicology, Georgia Regents University, Augusta, GA, USA \\ ${ }^{2}$ Department of Anesthesiology and Perioperative Medicine, Georgia Regents University, Augusta, GA, USA \\ ${ }^{3}$ Vascular Biology Center, Georgia Regents University, Augusta, GA, USA \\ ${ }^{4}$ Department of Medicine, Georgia Regents University, Augusta, GA, USA \\ ${ }^{5}$ Department of Physiology, Georgia Regents University, Augusta, GA, USA \\ ${ }^{6}$ Department of Cell Biology and Anatomy, Georgia Regents University, Augusta, GA, USA \\ 7 Department of Ophthalmology, Georgia Regents University, Augusta, GA, USA \\ ${ }^{8}$ VA Medical Center, Georgia Regents University, Augusta, GA, USA \\ ${ }^{9}$ Intellectual and Developmental Disabilities Research Center/Neuropsychiatric Institute (IDDRC/NPI), University of California Los Angeles School of Medicine, \\ Los Angeles, CA, USA \\ ${ }^{10}$ Division of Pulmonary Medicine, Georgia Regents University, Augusta, GA, USA
}

\section{Edited by:}

Charles Dinarello, University of

Colorado Health Sciences Center,

USA

Reviewed by:

Daisuke Kamimura, Osaka University,

Japan

Yongsheng Li, Harvard Medical

School, USA

\section{*Correspondence:}

Maritza J. Romero, Departments of Pharmacology and Toxicology and Anesthesiology and Perioperative Medicine, Vascular Biology Center, Georgia Regents University, 1459 Laney Walker Blvd, Augusta, GA 30912-2300, USA

e-mail:mromerolucas@gru.edu
Rationale: Diabetic nephropathy (DN) is a major cause of end-stage renal disease, associated with endothelial dysfunction. Chronic supplementation of L-arginine (L-arg), the substrate for endothelial nitric oxide synthase (eNOS), failed to improve vascular function. L-Citrulline (L-Cit) supplementation not only increases L-arg synthesis, but also inhibits cytosolic arginase I, a competitor of eNOS for the use of L-arg, in the vasculature.

Aims: To investigate whether L-cit treatment reduces DN in streptozotocin (STZ)-induced type 1 diabetes (T1D) in mice and rats and to study its effects on arginase II (Argll) function, the main renal isoform.

Methods: STZ-C57BL6 mice received L-cit or vehicle supplemented in the drinking water. For comparative analysis, diabetic Argll knock out mice and L-cit-treated STZ-rats were evaluated.

Results: L-Citrulline exerted protective effects in kidneys of STZ-rats, and markedly reduced urinary albumin excretion, tubulo-interstitial fibrosis, and kidney hypertrophy, observed in untreated diabetic mice. Intriguingly, L-cit treatment was accompanied by a sustained elevation of tubular Argll at 16 weeks and significantly enhanced plasma levels of the anti-inflammatory cytokine IL-10. Diabetic Argll knock out mice showed greater blood urea nitrogen levels, hypertrophy, and dilated tubules than diabetic wild type (WT) mice. Despite a marked reduction in collagen deposition in Argll knock out mice, their albuminuria was not significantly different from diabetic WT animals. L-Cit also restored nitric oxide/reactive oxygen species balance and barrier function in high glucose-treated monolayers of human glomerular endothelial cells. Moreover, L-cit also has the ability to establish an anti-inflammatory profile, characterized by increased IL-10 and reduced IL-1 $\beta$ and IL-12(p70) generation in the human proximal tubular cells.

Conclusion: L-Citrulline supplementation established an anti-inflammatory profile and significantly preserved the nephron function during T1D.

Keywords: arginase, L-citrulline, glomerulosclerosis, diabetic nephropathy, IL-10

\section{INTRODUCTION}

Patients with Type 1 diabetes (T1D) have a considerably worse long-term prognosis than individuals without diabetes, due to the high incidence of cardiovascular disease and end-stage renal disease (ESRD). Diabetic nephropathy (DN), the leading cause of chronic kidney disease in the United States, is responsible for up to $40 \%$ of all ESRD cases (1). Since conventional or recently proposed therapies toward DN are still under ongoing investigation, or lack major efficacy, the search for novel targets involved in diabetes-induced renal damage is of primary importance.

It is now generally recognized that dysfunction of endothelial nitric oxide synthase (eNOS) contributes to vascular pathology in diabetes. An important cause of impaired endothelial nitric oxide (NO) production is the reduced availability of the eNOS substrate 
$\mathrm{L}$-arginine ( $\mathrm{L}$-arg). Patients with diabetes and cardiovascular disease were shown to benefit from acute L-arg supplementation (2), but chronic L-arg therapy caused adverse effects (3).

Oral L-citrulline ( $\mathrm{L}$-cit, precursor of $\mathrm{L}$-arg) increases circulating levels of L-arg and augments NO-dependent signaling $(4,5)$, not only by means of increasing $\mathrm{L}$-arg synthesis but also by decreasing L-arg catabolism (6). The latter activity occurs due to L-cit's capacity to allosterically inhibit arginase I (ArgI), an enzyme which can impair eNOS function $(7,8)$. As such, this dual effect of $\mathrm{L}$-cit makes it a suitable supplemental amino acid to provide sufficient L-arg for proper eNOS function. In this regard, L-cit has been shown to prevent coronary vascular dysfunction in diabetic rats (8), with concomitant reduction of endothelial ArgI activity, which was also recently shown to contribute to coronary endothelial dysfunction in patients with diabetes mellitus (9) and in diabetic mice (10).

The effects of $\mathrm{L}$-cit on vascular endothelial function may also positively influence the endothelial glycocalyx, thus contributing to glomerular barrier preservation $(11,12)$. However, L-cit supplementation has been neither evaluated in a model of diabetic kidney disease, nor its effects on renal arginase. In the kidneys, arginase II (ArgII) is the only isoform expressed in mouse and humans (13). ArgII is present in the proximal tubules (PT) and in the inner medullary collecting ducts (14) and plays an important role in renal physiology and homeostasis (15). Arginase metabolizes L-arg to urea and ornithine. Whereas urea has a key role in the urinary concentrating mechanism (16), ornithine is the substrate for the ornithine/polyamine and ornithine/proline pathways. Both of these pathways play an important role in kidney physiology and pathology (17-19). Indeed, production of polyamines enhances progression of the cell cycle and is associated with cell survival (20). Proline, on the other hand, is a precursor needed for collagen synthesis (21). Thus, although these mechanisms are important to maintain kidney function, they may also contribute to kidney hypertrophy and glomerulosclerosis of diabetes. Up-regulation of renal ArgII, proposed to be a mediator of $\mathrm{DN}$, may play a role in these processes (22). However, L-cit supplementation to newborn rats was accompanied by enhanced ArgII expression in lungs, but it still protected from pulmonary hypertension (23).

In this study, we determined whether L-cit supplementation to streptozotocin (STZ)-diabetic rodents blunts the development of $\mathrm{DN}$, and whether L-cit has an effect on renal ArgII.

\section{MATERIALS AND METHODS ANIMALS AND DIABETIC MODEL}

Experiments were performed with C57BL/6 wild type (WT) mice (Jackson Laboratories, Bar Harbor, ME, USA), or ArgII homozygous knockout mice on a C57BL/6 background $(24,25)$. Ten-week old male mice (18-20 g) were rendered diabetic with intraperitoneal injections of STZ $(65 \mathrm{mg} / \mathrm{kg}$ ) (Sigma Aldrich, St. Louis, MO, USA), on alternating days for up to four injections (10). A group of control (vehicle) and diabetic mice were treated with L-cit (50 mg kg-1 day $^{-1}$, supplemented in drinking water) (8). Animals were housed in individual cages. The L-cit dose was adjusted to each animal according to the daily water intake. Mice were studied after 2 and 16 weeks with diabetes. In addition, male Sprague-Dawley rats (Charles River Laboratories, Raleigh, NC, USA), weighing between 225 and $250 \mathrm{~g}$, were rendered diabetic with a single dose of STZ (50 mg/kg, intraperitoneally). A group of diabetic rats $(\geq 350 \mathrm{mg} / \mathrm{dl})$ was treated with $\mathrm{L}$-cit, as indicated above. Rats were studied after 8 weeks with diabetes. Animals had free access to food and water throughout the study. All animals received humane care in compliance with federal laws and institutional guidelines at Georgia Regents University.

\section{MEASUREMENT OF KIDNEY HYPERTROPHY}

Determination of kidney to body weight ratio was used as a measure of kidney hypertrophy. The left kidney was removed, decapsulated, placed on tissue paper for $1 \mathrm{~min}$, and weighed.

\section{ANALYTICAL METHODS}

Mouse urinary albumin excretion (UAE), and rat proteinuria were determined after $24 \mathrm{~h}$ urine collection, using an ELISA kit (AssayPro, St. Charles, MO, USA), and a protein assay kit (BCA Pierce, Rockford, IL, USA), respectively. Blood glucose levels were measured by the Alpha Trak-Blood glucose monitoring system (Abbott Laboratories, St. Clara, CA, USA). Plasma urea levels were measured by colorimetric determination of urea at $540 \mathrm{~nm}$ in the presence of $\alpha$-Isonitrosopropiophenone ( $\alpha$-ISPF, 9\% in ethanol) (Sigma Aldrich, St. Louis, MO, USA). Results were expressed as milligram per deciliter of blood urea nitrogen (BUN). Mouse plasma samples, separated from heparinized whole-blood, were used for the measurement of 32 cytokines and chemokines, using a magnetic bead-based multiplex assay, as described in Ref. (26) (32 Multiplex MCYTOMAG-70K assay, EMD Millipore).

\section{TISSUE HISTOLOGY}

After being excised and decapsulated, mouse kidneys were immersed in $10 \%$ formalin for $24 \mathrm{~h}$, embedded in paraffin and sectioned at $4 \mu \mathrm{m}$ thickness. Sections were deparaffinized in xylene, rehydrated through graded ethanols to water, and stained with periodic acid Schiff (PAS) for morphology evaluation. Picro-Sirius red was used to stain for tissue collagen. Rat kidneys were frozen in liquid nitrogen, and cryosections $(5 \mu \mathrm{m})$ were air-dried for 30 min. Cryosections stained with Picro-sirius red were processed as previously described in Ref. (27). All PAS and Picro-sirius redstained sections were visualized on a computer connected to a light microscope (AxioVision; Carl Zeiss Meditec, Inc.). Quantitative analysis of collagen was performed on photomicrographs of kidney sections by using specific software (Image J). Seven to ten non-overlapping fields per section were analyzed for each animal. Tissue collagen content was assessed by a fibrosis index (\%) that indicated the ratio of the mean sirius red-stained area to the mean whole area of the section, calculated as the mean of the fibrosis indexes for each section for each animal.

\section{RENAL ARGINASE ACTIVITY}

Renal arginase activity (RAA) was measured in kidney cortex homogenized in ice-cold lysis buffer $(50 \mathrm{mmol} / \mathrm{L}$ Tris- $\mathrm{HCl}$, $0.1 \mathrm{mmol} / \mathrm{L}$ EDTA and EGTA, pH 7.5) at 1:4 (wt:vol) ratio, containing protease inhibitors. The homogenate was centrifuged at $14,000 \times g$ for $20 \mathrm{~min}$. The supernatant was removed for enzyme assay using a colorimetric determination of urea production from L-arg, as previously described in Ref. (28). Samples were assayed in triplicate. Values were corrected by adjusting for protein concentration in the homogenate and expressed as nanomole urea per milligram protein per hour. Additional corrections were made 
after subtracting basal levels of urea obtained from each sample of kidney cortex homogenates in the absence of $\mathrm{MnCl}_{2}$ and of $\mathrm{L}$-arg.

\section{WESTERN BLOT ANALYSIS}

Mouse and rat frozen kidney cortex were pulverized and homogenized in RIPA lysis buffer (EMD Millipore, Billerica, MA, USA), containing protease and phosphatase inhibitor cocktails (Sigma Aldrich, St. Louis, MO, USA). Soluble protein extracts from tissue homogenates were subjected to SDS-PAGE electrophoresis, transferred to polyvinylidene fluoride membranes and reacted with anti-ArgII primary antibody (1:500, Santa Cruz Biotechnology, St. Cruz, CA, USA), at $4^{\circ} \mathrm{C}$ overnight. Subsequently, the bound antibody was detected by donkey anti-rabbit horseradish peroxidase-labeled secondary antibody (1:6,000, GE Healthcare, Pittsburgh, PA, USA), and visualized with ECL substrate (Amersham, Buckinghamshire, UK). Membranes were then stripped and re-probed with anti-GAPDH (Santa Cruz Biotechnology, St. Cruz, CA, USA) to assess level of protein loading. Protein expression was determined using densitometry analysis of films.

\section{IMMUNOHISTOCHEMISTRY}

Immunohistochemical detection of ArgII was performed in deparaffinized and rehydrated mouse kidney sections by means of light microscopy studies. Briefly, antigen retrieval was performed by immersing the slides in $0.01 \mathrm{M}$ citrate buffer ( $\mathrm{pH} \mathrm{6.0)}$ ), at $95^{\circ} \mathrm{C}$ for $30 \mathrm{~min}$ in a water bath. Endogenous biotin and peroxidase activity were blocked before staining, by using commercial avidin/biotin and peroxidase kits, respectively (Vector Laboratories, Burlingame, CA, USA). Slides were then incubated for $1 \mathrm{~h}$ with primary antibody against ArgII (1:500). The primary antibody was localized using the VECTASTAIN ABC-Elite peroxidase detection system (Vector Laboratories, Burlingame, CA, USA). Primary antibody against kidney injury molecule 1 (KIM1) (1:500, R\&D Systems, Minneapolis, MN, USA), followed by anti-goat secondary antibody (1:6,000, Invitrogen, Grand Island, NY, USA), were used for immunofluorescent staining of rat frozen sections. Nuclei were counterstained with DAPI. All sections were examined by two different researchers in a blinded manner. The number of tubules that exhibited positive red fluorescent staining to KIM-1 was counted per field. Five to seven fields were examined in each kidney section. Sections of each kidney were processed in parallel with the appropriate negative control tissue, processed with omission of the primary antibody in the staining procedure.

\section{HUMAN GLOMERULAR ENDOTHELIAL CELL CULTURE}

Human glomerular endothelial cells (Lonza, Walkersville, MD, USA) were grown in complete CSC medium, and maintained at $37^{\circ} \mathrm{C}$ in a humidified $5 \% \mathrm{CO}_{2}$ incubator. Cells were used between passages four and six for the experiments. Treatment of cells with normal (5.5 mM, NG) or high [25 mM, high glucose (HG)] D-glucose-supplemented medium was performed in basic CSC medium. As control for the osmotic effect of high D-glucose, Lglucose was added to the basic endothelial medium. Pre-treatment of HGEC with L-cit ( $1 \mathrm{mM}$ ) was performed by adding the amino acid $2 \mathrm{~h}$ prior to adding $\mathrm{HG}$ or iso-osmotic control. HGEC were cultured under NG or HG conditions for either $24 \mathrm{~h}$ or 14 days, before they were used for experiments.

\section{MITOCHONDRIAL SUPEROXIDE}

Human glomerular endothelial cells were seeded in $0.2 \%$ gelatincoated four well slide chambers at $1 \times 10^{5}$ cells per well, and allowed to reach confluence. Then cells were exposed to HG for $24 \mathrm{~h}$ as described above, with or without pre-treatment with $\mathrm{L}$ cit. At the end of incubation, MitoSOX (Invitrogen) $5.0 \mu \mathrm{M}$ was added to the cells and incubated further for $10 \mathrm{~min}$ at $37^{\circ} \mathrm{C}$ in $5 \% \mathrm{CO}_{2}$ atmosphere, according to manufacturing instructions. Subsequently, cells were washed in hanks balanced salt solution (HBSS, with $\mathrm{Ca} / \mathrm{Mg}$ ) and used for confocal microscopy imaging. The digital images were taken by an inverted confocal laser scanning microscope LSM Pascal (Zeiss, Germany), with an excitation/emission of 510/580 nm. Images were captured using $40 \times$ oil immersion objective lens.

\section{NITRIC OXIDE METABOLITE}

Human glomerular endothelial cell were seeded at $1 \times 10^{5}$ cells per well in 24-well plates. Confluent quiescent cell monolayers were exposed to HG or proper iso-osmotic control for $24 \mathrm{~h}$. L-Cit ( $1 \mathrm{mM}$ ) was applied $2 \mathrm{~h}$ prior to HG. Exposure was terminated by removal of the supernatant. Fresh basic CSC medium was replaced and cells incubated for additional $30 \mathrm{~min}$. Supernatant was then removed, subsequently centrifuged and stored at $-80^{\circ} \mathrm{C}$ for $\mathrm{NO}$ analysis. Cell supernatants containing nitrite $\left(\mathrm{NO}_{2}^{-}\right)$the stable breakdown product of $\mathrm{NO}$ in aqueous medium were refluxed in glacial acetic acid containing sodium iodide. $\mathrm{NO}_{2}^{-}$is quantitatively reduced to $\mathrm{NO}$ under these conditions, which can be quantified by a chemiluminescence detector in a NO analyzer (Sievers) as described in Ref. (8).

\section{PERMEABILITY ASSAY OF HGEC MONOLAYERS}

Human glomerular endothelial cell monolayer permeability to high molecular mass proteins was assayed by using $2,000-\mathrm{kDa}$ FITC-dextran, based on the Transwell model (EMD Millipore). For this, HGEC were seeded on collagen-coated Transwells at a density of $1 \times 10^{5}$ cells per well in $250 \mu$ l of CSC growth medium. The inserts were placed into 24 -well plates containing $500 \mu \mathrm{l}$ of medium. Upon reaching confluence, HGEC were exposed to HG as described above, with or without pre-treatment with L-cit. Transendothelial passage of dextran was determined after 14 days of incubation in HG media as described previously (12). Briefly, medium was aspirated and $150 \mu$ l of FITC-dextran was added into the insert and incubated for $3 \mathrm{~h}$. The insert was then removed, and $100 \mu \mathrm{l}$ of medium was collected from the bottom chamber and transferred to a black 96-well plate. The fluorescent density of samples was analyzed on a Paradigm Microplate Fluorometer (Beckman-Coulter) at $485 \mathrm{~nm}$ excitation and $530 \mathrm{~nm}$ emission wavelengths.

\section{HUMAN PROXIMAL TUBULAR EPITHELIAL CELL CULTURE}

Human proximal tubular epithelial cell (huPTEC) (Lifeline Cell Technology, Frederick, MD, USA) were grown in the commercial RenaLife medium, and maintained at $37^{\circ} \mathrm{C}$ in a humidified $5 \% \mathrm{CO}_{2}$ incubator. Cells were used between passages two and four for the experiments. Treatment of cells with normal (5.5 mM, NG) or high (25 mM, HG) D-glucose-supplemented medium was performed in six-well plates and maintained 
for 7 days, before they were used for experiments. As control for the osmotic effect of high D-glucose, L-glucose was added to the culture medium. Pre-treatment of huPTEC with $\mathrm{L}$-cit $(1 \mathrm{mM})$ was performed by adding the amino acid $2 \mathrm{~h}$ prior to adding HG or iso-osmotic control, with or without concurrent pre-treatment with a neutralizing anti-human IL-10 antibody ( $5 \mu \mathrm{g} / \mathrm{ml}, \mathrm{R} \& \mathrm{D}$ Systems). Upon completion of treatment, culture medium supernatants were collected, centrifuged, and freeze at $-80^{\circ} \mathrm{C}$ until use for cytokine measurement. Cells were lysed in RIPA buffer and protein extracts were loaded for Western blot analysis of ArgII as described for tissue extracts.

\section{MULTIPLEX HUMAN CYTOKINE/CHEMOKINE MEASUREMENT}

A panel of 13 pro-inflammatory cytokines [interferon- $\gamma$ (IFN- $\gamma$ ), IL-1 $\beta$, IL-2, IL-4, IL-5, IL-6, IL-7, IL-8, IL-10, IL-12p70, IL-13, TNF, and granulocyte-monocyte colony-stimulating factor (GM-CSF)] was assessed in triplicates in $50 \mu \mathrm{l}$ cultured medium supernatants from cultured primary huPTEC, using a highly sensitive magnetic beads-based kit (MILLIPLEX MAP High Sensitivity Human Cytokine Panel - Premixed 13 Plex, EMD Millipore) (29). This assay has a high sensitivity, typically with a detection limit in the range from 0.01 to $0.48 \mathrm{ng} / \mathrm{l}$.

\section{IMMUNOFLUORESCENCE STAINING OF CULTURED huPTEC}

Cells were seeded in slide chambers at $1 \times 10^{5}$ cells per well. When cells reached about $75-80 \%$ confluence, HG was added for 1 week as described above, with or without pre-treatment with L-cit. Upon completion of treatment, cells were washed twice with PBS and fixed with $4 \%$ paraformaldehyde for $15 \mathrm{~min}$. Then, a blocking solution (1X PBS/5\% normal goat serum $/ 0.3 \%$ Triton $^{\mathrm{TM}} \mathrm{X}-100$ ) was applied to the attached cells in the slide chambers for $1 \mathrm{~h}$, prior to addition of anti-caspase 6 antibody (1:800, Cell Signaling, Boston, MA, USA) for incubation overnight at $4^{\circ} \mathrm{C}$. Cells were washed twice with PBS and incubated with a fluorochrome-conjugated secondary antibody (1:400, Cy5 goat anti-rabbit, Jackson ImmunoResearch). DAPI was used for nuclear staining. For non-specific binding (negative control) the primary antibody was omitted. Images were collected with fluorescent microscopy. Fluorescence intensity measurements were performed in nuclei, normalized to DAPI nuclei area, and corrected by subtraction of background from negative controls.

\section{STATISTICAL ANALYSIS}

All data were expressed as mean \pm SEM. Statistical analysis was performed by one-way ANOVA with a Tukey post test. In some experiments, statistical differences were determined by a Student's $t$-test. A $p$ value of $<0.05$ was considered statistically significant.

\section{RESULTS}

BLOOD GLUCOSE, WATER CONSUMPTION, URINE VOLUME, BODY WEIGHT, KIDNEY WEIGHT, AND BUN IN MICE

All diabetic groups had elevated blood glucose levels and increased daily water intake and urinary volume excretion, both at 2 (Table 1) and 16 weeks (Table 2 ) of the disease vs. respective nondiabetic controls. The kidney hypertrophy and wasting of body mass detected in untreated diabetic WT mice was not observed in L-cit-treated mice, despite significant hyperglycemia (Tables 1 and 2). Intriguingly, although ArgII has been proposed to be a mediator of DN (22), we observed a significant greater kidney size and BUN levels in the ArgII knock out mice, as compared to diabetic WT animals (Table 2). These results indicate that $\mathrm{L}$-cit does not affect blood glucose levels in the diabetic state, but prevents body weight loss and kidney hypertrophy. In addition, the results observed in the ArgII knock out mice suggest that the lack of ArgII enhances diabetes-induced kidney hypertrophy and may accelerate the decay of kidney function in diabetic mice.

\section{RENAL ARGINASE ACTIVITY AND ArgII PROTEIN LEVELS}

At 2 weeks, RAA was elevated in untreated diabetic WT mice by 8.6-fold over control. By contrast, L-cit-treated diabetic WT mice showed only twofold elevated RAA levels over control values (Figure 1A). The marked elevation of RAA, observed at 2 weeks in untreated diabetic WT mice, declined by 16 weeks to a level of $\sim 2.4$-fold over respective control. At that time period, diabetic WT mice treated with $\mathrm{L}$-cit showed a rise in RAA of 3.8-fold over control (Figure 1B). These results indicate that diabetes strongly induces arginase activity in renal tissues, and that long-term supplementation of L-cit does not prevent this effect. The absence of the ArgII gene in both control and diabetic ArgII knock out mice, resulted in RAA values below control WT mice by 0.2 - and 0.3 fold, respectively. These low levels of arginase activity could be due to the presence of vascular and blood cell-derived ArgI.

Western blot analysis of protein extracts from kidney cortex homogenates of untreated diabetic WT mice showed levels

Table 1 | Biochemical and physical characteristics of study groups after 2 weeks. Effect of L-cit supplementation.

\begin{tabular}{|c|c|c|c|c|c|}
\hline & Blood glucose (mg/dl) & Water intake (ml/day) & Urine volume (ml/day) & Body weight (g) & $\mathrm{K} / \mathrm{BW}$ ratio \\
\hline Control & $103.8 \pm 8.2$ & $7 \pm 0.9$ & $1.55 \pm 0.2$ & $23 \pm 0.7$ & $5.97 \pm 0.4$ \\
\hline Diabetic & $460.3 \pm 71.7^{a}$ & $19.5 \pm 2.4^{b}$ & $14.5 \pm 1.4^{\mathrm{C}}$ & $19 \pm 0.5^{d}$ & $8.53 \pm 0.03^{d}$ \\
\hline L-Cit-Con & $132.3 \pm 11.1$ & $7.2 \pm 0.6$ & $1.4 \pm 0.4$ & $26 \pm 1.3$ & $6.39 \pm 0.4$ \\
\hline L-Cit-Diab & $465.8 \pm 96.4^{a}$ & $17.5 \pm 1.1^{b}$ & $9.6 \pm 2.4^{c}$ & $25 \pm 0.4$ & $5.85 \pm 0.1$ \\
\hline
\end{tabular}

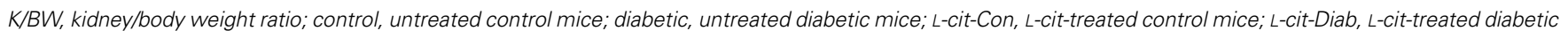
mice. Values are expressed as mean \pm SEM.

${ }^{a} p<0.001$ vs. control groups; ${ }^{b} p<0.01$ vs. control groups; ${ }^{c} p<0.05$ vs. control groups; ${ }^{d} p<0.01$ vs. all groups. 
Table 2 | Biochemical and physical characteristics of study groups after 16 weeks. Effect of L-cit supplementation and Argll deletion.

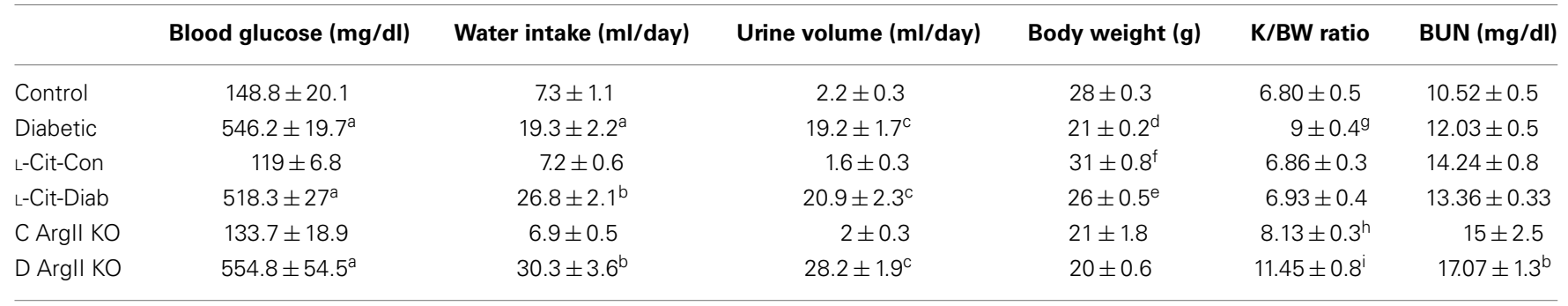

K/BW, kidney/body weight ratio; BUN, blood urea nitrogen; control, untreated control WT mice; diabetic, untreated diabetic WT mice; L-cit-Con, L-cit-treated control WT mice; L-cit-Diab, L-cit-treated diabetic WT mice; C Argll KO, control Argll knock out mice; D Argll KO, diabetic Argll knock out mice. Values are expressed as mean \pm SEM.

${ }^{a} p<0.01$ vs. all control groups; ${ }^{b} p<0.05$ vs. all groups; ${ }^{c} p<0.05$ vs. all control groups; ${ }^{d} p<0.001$ vs. control and L-cit-Con; ${ }^{e} p<0.001$ vs. diabetic; ${ }^{f} p<0.001$ vs. L-cit-Diab; ${ }^{g} p<0.01 \mathrm{vs.} \mathrm{control}$ and Lcit-Con; ${ }^{h} p<0.05 \mathrm{vs}$. control; $i p<0.01 \mathrm{vs.} \mathrm{all} \mathrm{groups.}$

of ArgII protein that were increased up to 10 -fold over control at 2 weeks (Figure 1C). ArgII protein in tissues from L-cittreated diabetic WT mice were $\sim$ fivefold higher than in controls (Figure 1C). Conversely, upon progression of diabetes to 16 weeks, the highest levels of ArgII protein were observed in L-cittreated diabetic WT mice (Figure 1D). ArgII was neither detected in control nor in diabetic ArgII knock out mice (Figure 1D). These results indicate that the induction of arginase activity observed in kidney cortex of diabetic mice is due to increased protein levels of ArgII. L-Cit does not prevent diabetes-induced ArgII up-regulation, and may even have an additive effect upon long-term supplementation.

\section{IMMUNOHISTOCHEMISTRY}

Diffuse ArgII immunoreactivity was observed in cells of the urinary pole of the Bowman's capsule, and of the PT of untreated control WT mouse kidneys. Enhanced tubular ArgII staining was detected in untreated diabetic WT mice after 16 weeks of the disease (Figure 2A). L-Cit-treated diabetic WT mice also demonstrated increased ArgII immunoreactivity in cortical tubular segments, while maintaining a more conserved epithelial morphology (Figure 2A). No positive staining was observed in either the ArgII knock out mouse kidneys (Figure 2B), or in tissue sections stained in parallel with omission of primary antibody (Figure 2C).

\section{URINARY ALBUMIN EXCRETION}

Urinary albumin excretion was significantly elevated above control in untreated diabetic WT mice as early as 2 weeks, but this effect was markedly blunted upon L-cit treatment (untreated diabetic: $811.43 \pm 161.04 \mu \mathrm{g} / \mathrm{ml}$ vs. control: $97.73 \pm 29.6 \mu \mathrm{g} / \mathrm{ml}$, and L-cit-treated diabetic: $138.47 \pm 47.3 \mu \mathrm{g} / \mathrm{ml}, p<0.05)$. This preventive effect of $\mathrm{L}$-cit on urinary albumin leakage was observed for up to 16 weeks, while non-treated diabetic WT mice maintained elevated UAE at that time point (Figure 3). Urine samples from diabetic ArgII knock out mice showed a trend to reduced albumin excretion, as compared to nontreated diabetic WT mice (Figure 3). These data thus indicate that L-cit may be protective toward diabetes-induced glomerular barrier dysfunction and/or impairment of proximal tubular protein uptake.

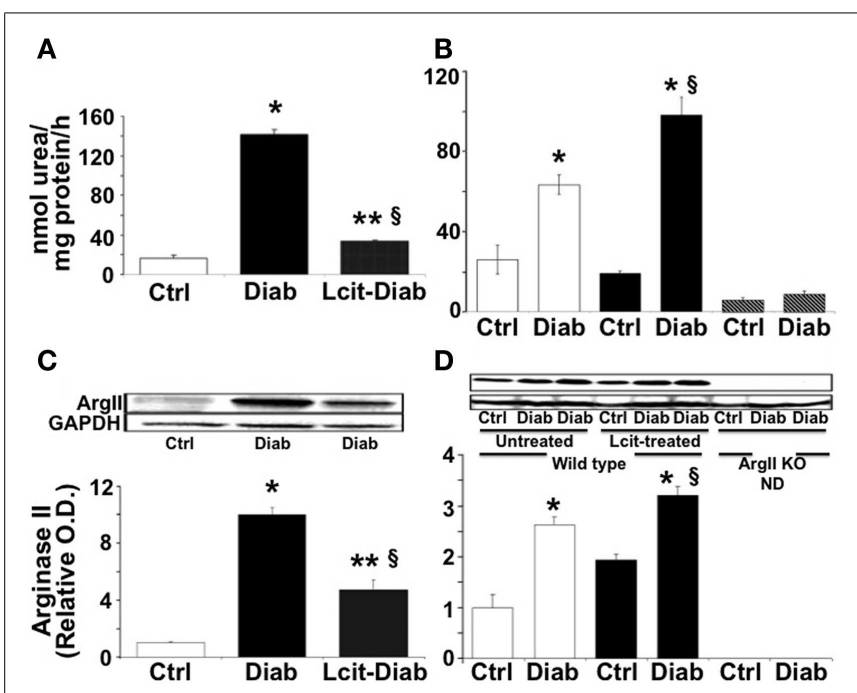

FIGURE 1 | Renal arginase. Kidney cortex isolated from mice after 2 (A-C) and 16 (B-D) weeks of diabetes was homogenized in lysis buffer. Arginase activity $(\mathbf{A}, \mathbf{B})$ was assayed using a colorimetric determination of urea production from L-arginine. Relative levels of arginase II protein expression (C,D) were determined by western blot analysis. Ctrl, control; Diab, diabetic; WT, wild type; Argll KO, Argll knock out; ND, not detected. Values are expressed as mean \pm SEM, $n=4-6$. (A-C) ${ }^{*} p<0.001$ vs. Ctrl, ${ }^{\S} p<0.01$ vs. Ctrl, ${ }^{*} p<0.001$ vs. Diab. (B-D) $\square$, Untreated WT; L-cit-treated WT; $\square$, Argll KO. ${ }^{*} p<0.01$ vs. untreated and L-cit-treated Ctrl WT, and Argll KO groups, ${ }^{\S} p<0.05$ vs. untreated Diab WT.

\section{RENAL HISTOLOGY}

Histological examinations of PAS-stained kidney sections of untreated diabetic WT mice at 16 weeks revealed glomerular hypertrophy, Bowman's capsule thickening and periglomerulosclerosis, in comparison to control mouse kidneys (Figures 4A,B). The PT showed hypertrophy and markedly thickened and wrinkled basement membranes. Interstitial expansion and focal areas of hypercellularity were also observed. Treatment of diabetic WT mice with L-cit markedly ameliorated all diabetesinduced alterations in the kidney. Intriguingly, we observed a marked dilatation of cortical tubules, focal blebbing of the luminal edge of the cells and detachment in the kidneys from diabetic 


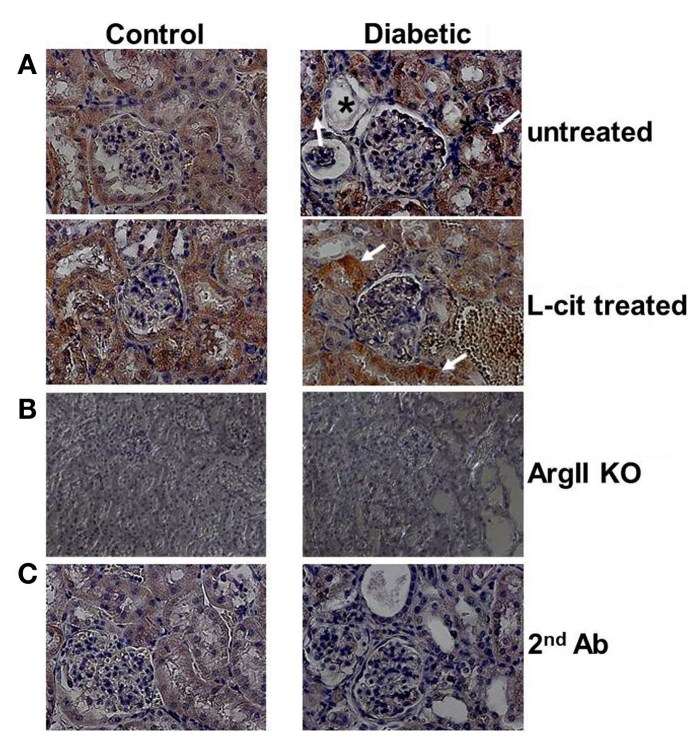

FIGURE 2 | Immunohistochemistry of Argll in paraffin-embedded mouse kidney sections. Representative photographs of paraffin-embedded kidney sections showing immunolocalization of Argll (brown color; $40 \times$ immersion oil). (A) Cortical tubular segments in untreated diabetic mice show higher stain density than untreated control mice, after 16 weeks (white arrows). Atrophic tubules with widened lumina and flattened tubular cells, or with altered epithelial morphology, show reduced Argll staining $\left({ }^{*}\right)$. L-Cit-treated diabetic mice show also enhanced Argll stain intensity (white arrows). Kidney segments of control and diabetic Argll knock out mice (B), or tubules stained with secondary antibody alone (C) were completely negative for Argll immunostaining.

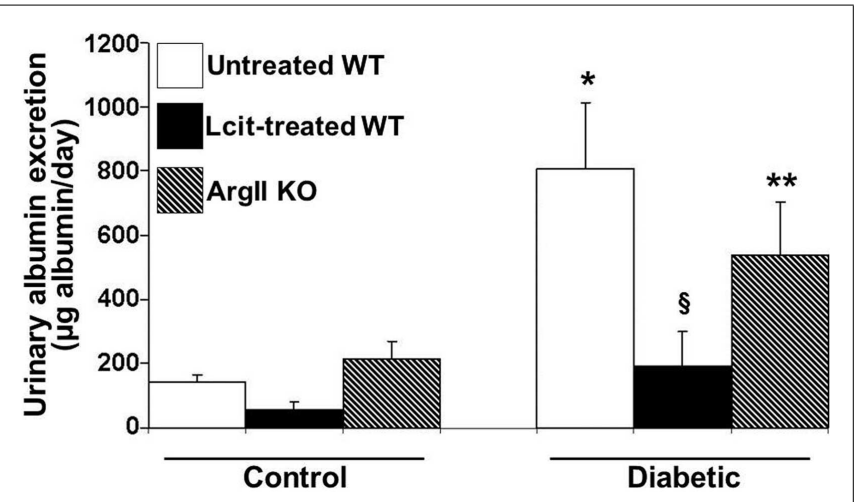

FIGURE 3 | Urinary albumin excretion (UAE) in mice after 16 weeks. Mice were placed in metabolic cages. Urine samples were collected for $24 \mathrm{~h}$ to determine albumin excretion. Values are expressed as mean $\pm \mathrm{SEM}$, $n=5-9$. WT, wild type; Argll KO, Argll knock out. * $p<0.001$ vs. untreated, L-cit-treated, and Argll KO control, ${ }^{\S} p<0.05$ vs. untreated diabetic WT, ${ }^{* *} p<0.05$ vs. untreated and L-cit-treated control WT.

ArgII knock out mice (Figures 4A,C). However, no thickening of tubular basement membrane was observed in this group.

As visualized in Figure 5A, picro-sirius red staining showed an enhancement of peri-glomerular and peritubular-interstitial collagen deposits in kidneys of WT diabetic mice at 16 weeks,

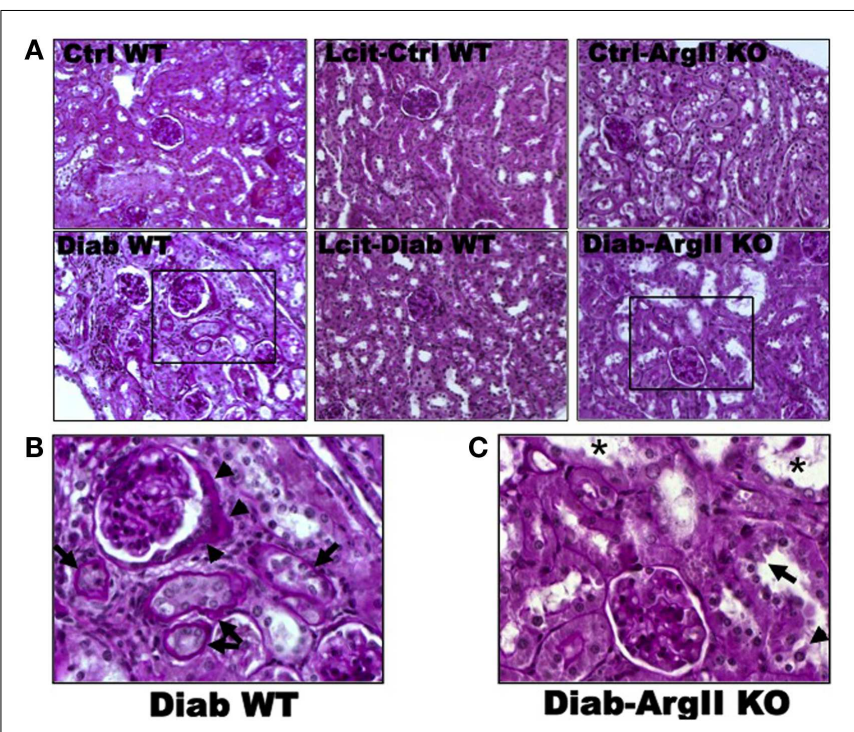

FIGURE 4 | Periodic acid Schiff-stained paraffin-embedded kidney sections. (A) Representative photomicrographs of PAS-stained kidney sections from: untreated (Cont WT) and L-cit-treated (Lcit-Cont WT) control wild type, and control Argll knock out (Ctrl-Argll KO) mice (upper). Untreated (Diab WT) and L-cit-treated (Lcit-Diab WT) diabetic wild type, and diabetic Argll knock out (Diab-Argll KO) mice (lower) at 16 weeks (20x). Morphological alterations of a selected area (rectangle) observed in Diab WT and Diab-Argll KO kidneys are shown at higher magnification (40x immersion oil) in: (B) a hypertrophied glomerulus with thickening of Bowman's capsule is observed (arrow heads). Surrounding tubules show markedly thickened and wrinkled tubular basement membranes, and partial disruption of brush border (arrows). Interstitial expansion and

hypercellularity around the glomerulus and surrounding tubules are also observed. These effects were markedly attenuated by L-cit treatment in diabetic mice. (C) Marked dilatation of cortical tubules (*), focal blebbing of the luminal edge (arrow), and focal detachment (arrow head) of epithelial cells in a proximal tubule.

as compared to control mice. This effect was reduced in L-citsupplemented WT diabetic mice (Figures 5A,B). Interestingly, induction of diabetes by STZ in ArgII knock out mice did not result in enhanced collagen deposits, as compared to diabetic WT mice (Figures 5A,B).

\section{ANTI-INFLAMMATORY EFFECT OF L-CIT IN DIABETIC MICE}

Because diabetes is considered a chronic inflammatory state (30), we examined the effect of L-cit supplementation on plasma cytokine levels in diabetic mice at the end of the experiment. We found enhanced levels of the pro-inflammatory cytokines TNF and IL- 6 in the diabetic animals, with the former being significantly different when compared to control mice (Figure 6). Strikingly, the level of the anti-inflammatory cytokine IL-10 was significantly enhanced in plasma of L-cit-treated diabetic mice (Figure 6). We also found significantly enhanced levels of the proinflammatory chemokine MIP-2 in diabetic vs. control mice (ctrl: $0.2+0.02 \mathrm{pg} / \mathrm{ml}$; STZ: $328.7 \pm 2.6 \mathrm{pg} / \mathrm{ml}, n=3, p<0.001 \mathrm{vs.} \mathrm{ctrl})$. However, there was a significant reduction of MIP-2 upon L-cit supplementation to diabetic mice (L-cit/STZ: $311.6 \pm 3.1 \mathrm{pg} / \mathrm{ml}$, $n=3, p<0.05$ vs. STZ, $p<0.001$ vs. ctrl). These results thus 


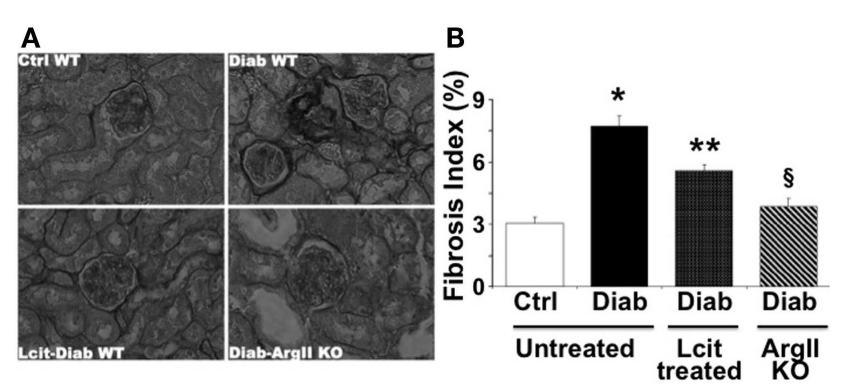

FIGURE 5 | Picro-sirius red staining of paraffin-embedded kidney sections. (A) Representative photomicrographs of picro-sirius red-stained kidney sections from untreated control wild type (Ctrl WT), untreated diabetic wild type (Diab WT), L-cit-treated diabetic wild type (Lcit-Diab WT), and diabetic Argll knock out (Diab-Argll KO) mice at 16 weeks (RGB image using Image J). Increased collagen deposits (dark color) are observed in Diab WT. This effect was significantly reduced in Lcit-Diab WT, and in Diab-Argll KO mice. (B) Fibrosis index (\%) of tissue collagen content that indicates the ratio of the mean picro-sirius red-stained area to the mean whole area of the section. Values are mean \pm SEM. ${ }^{*} p<0.001$ vs. untreated $\mathrm{Ctrl}$ WT, ${ }^{*}{ }^{*} p<0.01$ vs. untreated $\mathrm{Ctrl}$ and Diab WT, ${ }^{\S} p<0.001$ vs. untreated Diab WT

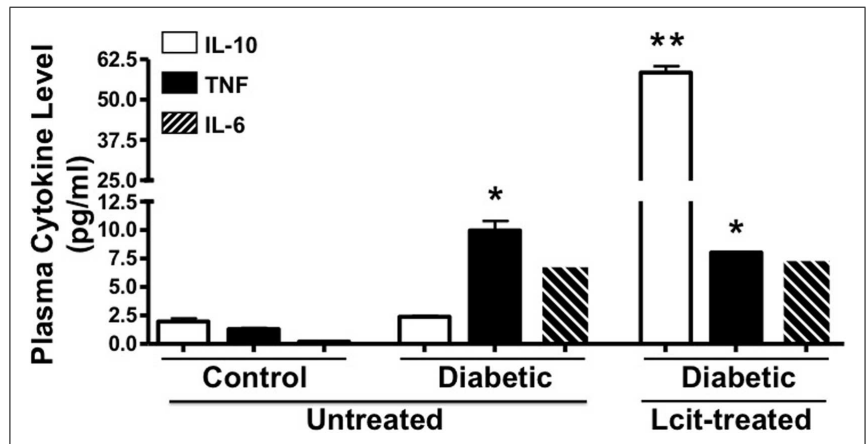

FIGURE 6 | Plasma cytokine level. Mouse plasma samples were used for cytokine and chemokine measurement, using a magnetic bead-based multiplex assay. L-Cit induced an anti-inflammatory response in diabetic mice, as observed by significant increased levels of IL-10. Values are mean \pm SEM. ${ }^{*} p<0.001$ vs. untreated control mice, ${ }^{* *} p<0.001$ vs. untreated control and diabetic mice.

indicate that $\mathrm{L}$-cit treatment increases the anti-inflammatory response in STZ-treated diabetic mice.

\section{EFFECTS OF L-CIT IN DIABETIC STZ-RATS}

Since C57BL6 mice develop only a moderate nephropathy upon STZ-treatment, we have also evaluated the effect of $\mathrm{L}$-cit treatment in a more sensitive rodent model of STZ-induced diabetes, i.e., the rat. STZ-diabetic rats had increased daily proteinuria, as compared to non-diabetic control rats. However, L-cit treatment prevented this effect (Figure 7A). In addition, kidneys from untreated diabetic STZ-rats showed characteristic features of human DN, as observed by substantial collagen deposits of intraglomerular and peritubular distribution (Figures $7 \mathbf{B}, \mathbf{C}$ ). These effects were reduced in L-cit-supplemented STZ-rats (Figures 7B,C). These findings were accompanied by an elevation of renal ArgII protein

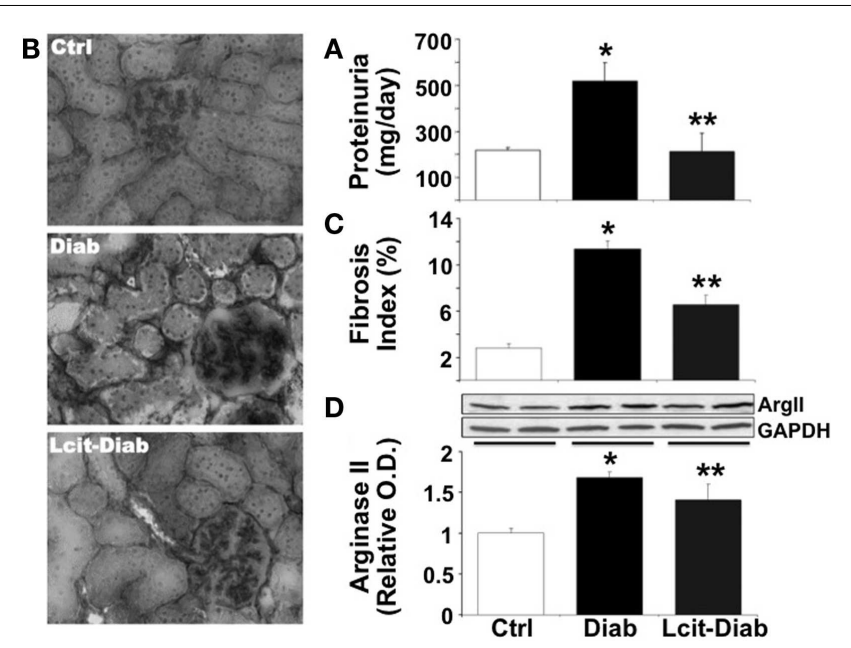

FIGURE 7 | Effect of l-cit on kidney pathology in STZ-rats. Urine and renal tissues from untreated control (Ctrl), untreated diabetic (Diab), and L-cit-treated diabetic (Lcit-Diab) rats were evaluated. (A) Rats were placed in metabolic cages for $24 \mathrm{~h}$ urine collection. Total protein excretion was measured in urine. Lcit-Diab rats had a significant reduction of proteinuria when compared to Diab rats. ${ }^{*} p<0.05$ vs. Ctrl, ${ }^{*} p<0.05$ vs. Diab. (B) Representative photomicrographs of frozen sections from rat kidneys stained with picro-sirius red, show enhanced collagen deposits (dark color, RGB image using Image $J$ ) in untreated diabetic rats. This effect was markedly blunted in L-cit-treated diabetic rats. (C) Fibrosis index (\%) of tissue collagen content that indicates the ratio of the mean picro-sirius red-stained area to the mean whole area of the section. ${ }^{*} p<0.001$ vs. Ctrl, ${ }^{* *} p<0.001$ vs. Diab. (D) Renal Argll protein expression determined by densitometric analysis of immunoblots performed with protein extracts from rat kidney cortex ( $n=4$, representative blot is shown). ${ }^{*} p<0.001$ vs. Ctrl rats, ${ }^{* *} p<0.05$ vs. Ctrl rats

levels in both, untreated and L-cit-treated diabetic STZ-rats, when compared to control non-diabetic rats (Figure 7D).

\section{RENAL EXPRESSION OF KIDNEY INJURY MOLECULE 1}

Kidney injury molecule 1 is a relevant biomarker of renal tubular damage that has been found to be associated with albuminuria in the early stage of nephropathy in diabetic patients (31), and with the progression of DN in experimental models (32). Therefore, we evaluated the expression of KIM-1 in kidneys of diabetic rats with or without L-cit supplementation. While renal tissues of control non-diabetic rats were negative for KIM-1 immunostaining, numerous tubular segments in the cortex and in the outer strip of the outer medulla were intensely stained in diabetic rats (Figure 8A). L-Cit-treated diabetic rats showed fewer positive tubules than untreated diabetic rats. An objective score of the number of positive tubules per field is shown in Figure 8B.

\section{EFFECT OF L-CIT IN HUMAN GLOMERULAR ENDOTHELIAL CELLS EXPOSED TO HIGH GLUCOSE}

Since HG-induced reactive oxygen species (ROS) generation is known to impair endothelial-derived NO production, we evaluated the effect of $\mathrm{L}$-cit on NO production in HGECs exposed to HG. L-Cit pre-treatment of HGECs prevented the impaired NO production observed under exposure to HG for $24 \mathrm{~h}$ (Figure 9A). This effect correlated with a marked attenuation of mitochondrial 


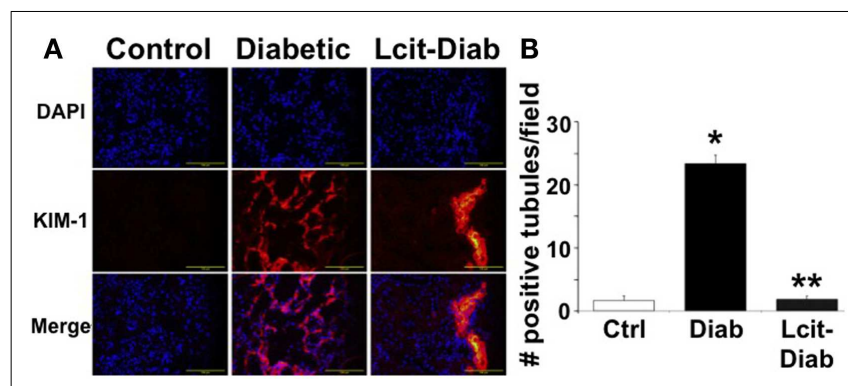

FIGURE 8 | KIM-1 immunofluorescence staining. Kidney injury molecule 1 (KIM-1) antibody was used for immunofluorescent staining (red) of frozen sections from control (Ctrl), untreated diabetic (Diab), and L-cit-treated diabetic (Lcit-Diab) rats. Nuclei were counterstained with DAPI (blue). (A) Representative photomicrographs show negative staining for $\mathrm{KIM}-1$ in control kidneys. Conversely, an increased number of tubules positively stained for KIM-1 is observed in kidneys of untreated diabetic rats. The number of positive tubules was dramatically decreased in kidneys of L-cit-treated diabetic rats. (B) Staining score determined by counting the number of positive tubules per field, using $40 \times$ magnification lens. Five to seven fields were examined in each kidney section $(n=3-4)$. ${ }^{*} p<0.001$ vs. Ctrl, ${ }^{* *} p<0.001$ vs. Diab.

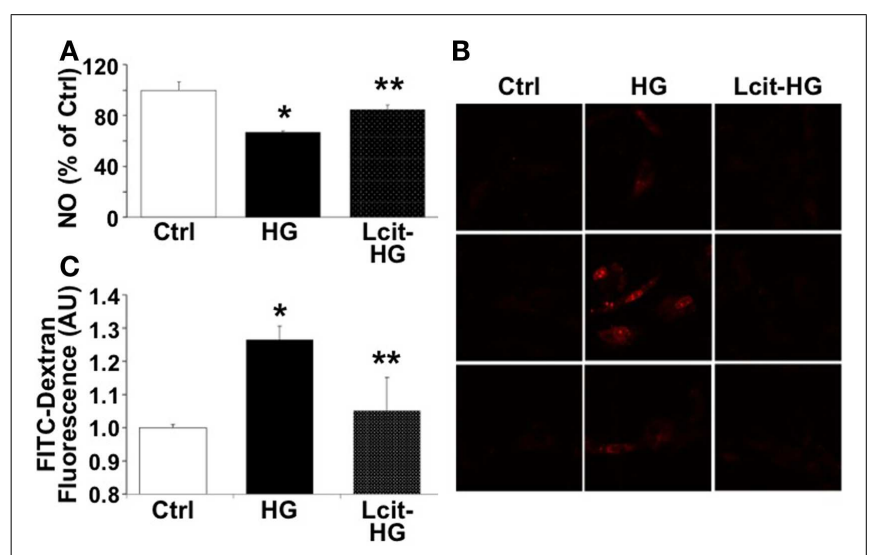

FIGURE 9 | Effect of L-cit on human glomerular endothelial cells exposed to high glucose. HGECs were cultured in basic CSC medium containing $25 \mathrm{mM}$ D-glucose (HG) with or without $1 \mathrm{M} \mathrm{L-cit} \mathrm{for} 24 \mathrm{~h}(\mathbf{A}, \mathbf{B})$ or 14 days $\mathbf{( C )}$. L-Glucose (19.5 mM) was added to $5.5 \mathrm{mM}$ D-glucose present in basic CSC medium, and used as iso-osmotic control (Ctrl). (A) The nitrite level (picomole) in the medium was determined by NO analyzer and expressed as percent of control $\left({ }^{*} p<0.01\right.$ vs. Ctrl, ${ }^{* *} p<0.05$ vs. HG, $n=3$ ). (B) HGECs were seeded onto gelatin-coated slide chambers. After completion of treatments, MitoSOX (a marker of mitochondrial superoxide, $5.0 \mu \mathrm{M})$ was added to the cells and incubated further for $10 \mathrm{~min}$. Cells were washed and used for confocal microscopy imaging. Representative images show increase in mitochondrial MitoSOX fluorescence following treatment with HG. This effect was markedly reduced by concurrent L-cit treatment. (C) Transendothelial passage of FITC-dextran was used to determine permeability of HGEC monolayer, seeded onto collagen-coated Transwells. Fluorescent density of samples was analyzed on a paradigm microplate fluorometer ( ${ }^{*} p<0.01$ vs. Ctrl, ${ }^{* *} p<0.05$ vs. HG, $n=4$ ).

superoxide generation, as opposed to the increase in mitochondrial red fluorescence intensity of MitoSOX in confocal microscopic images observed in HG-treated cells (Figure 9B).

Increasing evidence suggests that a NO/ROS imbalance causes endothelial barrier dysfunction (11). We therefore examined the effect of L-cit on HG-induced loss of barrier function in HGEC monolayers, by means of assessing their permeability to FITCdextran. As shown in Figure 9C, HG $(25 \mathrm{mM})$ significantly increased permeability of HGEC monolayers to FITC-dextran, but pre-treatment of the monolayers with $\mathrm{L}$-cit $(1 \mathrm{mM})$ conferred a significant protection from HG-induced hyperpermeability. These results suggest that $\mathrm{L}$-cit protects glomerular barrier function at least in part by preserving glomerular endothelial NO synthase (NOS) function, and by reducing ROS generation under hyperglycemic insult.

\section{EFFECT OF L-CIT IN HUMAN PROXIMAL TUBULAR EPITHELIAL CELLS EXPOSED TO HIGH GLUCOSE}

Proximal tubular cells are capable of generating IL-10 (33). Therefore, we investigated the effect of L-cit on cytokine production in huPTECs exposed to HG. huPTEC cultured under HG-supplemented medium in the presence of L-cit for 1 week, produced significantly enhanced levels of the anti-inflammatory cytokine IL-10, as compared to cells treated with HG alone (Figure 10A). This effect was accompanied by a significant reduction of levels of the pro-inflammatory cytokines IL-12 (p70) and IL-1 $\beta$, the generation of which is increased in cells cultured under HG-supplemented medium without L-cit cotreatment. Addition of a neutralizing antibody against IL-10 to huPTEC cultured under HG in the presence of L-cit, significantly abolished the reduction of IL-12 (p70). In addition, elevation of IL-10 was accompanied by significant elevated protein levels of ArgII, an effect that was partially reduced when anti-IL-10 antibody was added along with L-cit to the HGsupplemented medium (Figure 10B). These data indicate that elevation of ArgII in huPTEC in culture is a marker of the anti-inflammatory actions of $\mathrm{L}$-cit through its IL-10-inducing capacity.

We also examined the activation of the apoptotic marker caspase 6, which was shown to be involved in PTEC apoptosis during nephropathy (34). We observed an increased nuclear translocation of caspase 6 in huPTEC exposed to HG. L-Cit significantly blunted this effect of HG at least partially in an IL10-dependent manner, since concurrent treatment of huPTEC with a neutralizing IL-10 significantly prevented the reduction in caspase 6 nuclear translocation by L-cit (Figure 10C). This indicates that the observed caspase 6 activation was linked to a pro-inflammatory cytokine, the generation of which was inhibited by IL- 10 .

\section{DISCUSSION}

Hyperglycemia, which activates several reactions, including oxidative stress and chronic or subclinical inflammation, is clearly recognized as the primary player in diabetic endothelial dysfunction and DN (35-37).

It is now generally recognized that an important cause of impaired endothelial NO production, characteristic of diabetic endothelial dysfunction, is reduced availability of the eNOS substrate L-arg. Despite diverse data from studies assessing plasma amino acid levels in diabetic patients with or without chronic kidney disease $(38,39)$, patients with diabetes and cardiovascular disease were shown to benefit only from acute (2), but not from chronic (3) L-arg supplementation. 
A

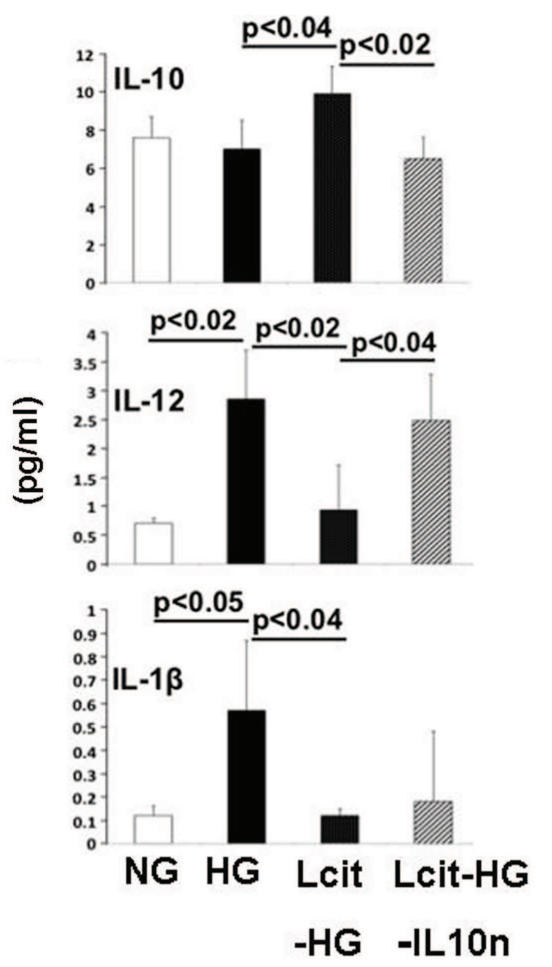

\section{B}
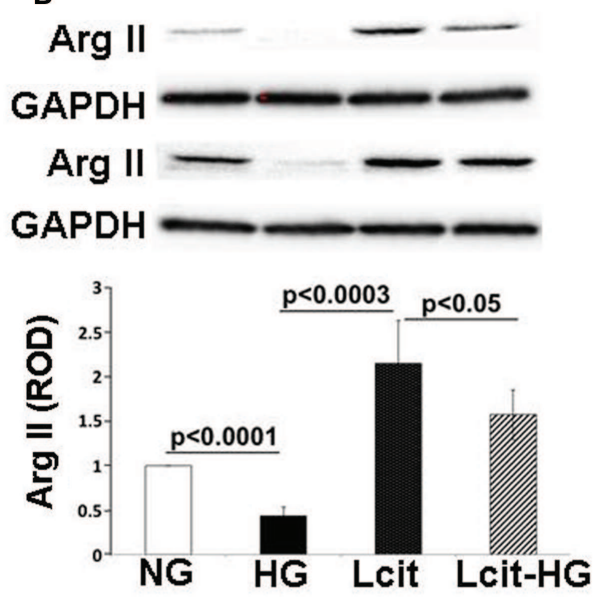

C
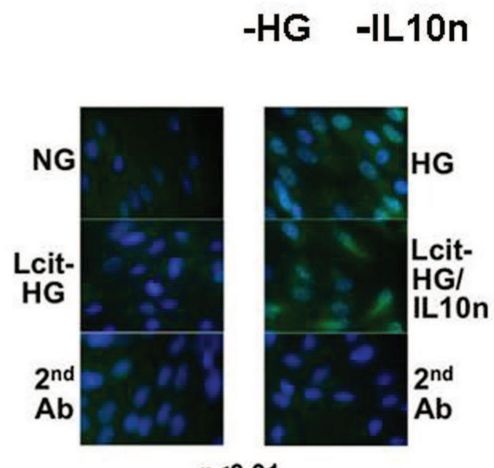

$\mathrm{p}<0.01$

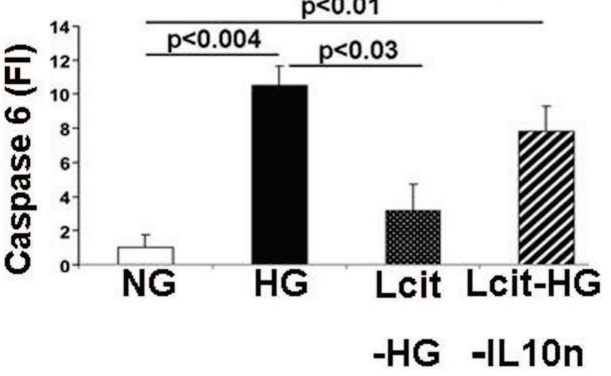

treatment with $\mathrm{HG}$. This effect was markedly reduced by concurrent L-cit treatment, while addition of anti-IL-10 antibody (IL10n) along with L-cit partially prevented L-cit-induced elevation of arginase II. (C) huPTEC were seeded onto slide chambers. After completion of treatments, cells were immunostained using caspase 6 as primary antibody, followed by Cy5-conjugated goat anti-rabbit secondary antibody. DAPI was used for nuclear staining. Representative images (upper) and microscopy analysis of nuclear fluorescence intensity (lower) show an increase nuclear localization of caspase 6 (green fluorescence) following treatment with HG. This effect was markedly reduced by concurrent L-cit treatment, while the effect was abolished by addition of neutralizing anti-IL-10 antibody (IL10n) along with L-cit.
Conversely, we and others have been shown that oral L-cit (precursor of L-arg) augments NO-dependent signaling, not only by means of increasing L-arg synthesis, but also by decreasing Larg catabolism, as such increasing circulating L-arg levels (4-6). However, the effects of L-cit on the development of diabetic kidney damage have not been studied. Therefore, in this study, we assessed the actions of supplemental $\mathrm{L}$-cit in a murine model of DN. Our data demonstrate that oral L-cit supplementation protects diabetic STZ-mice from the sustained elevation of UAE, as observed in untreated mice at 16 weeks of the disease. This protective effect of L-cit occurs despite significant hyperglycemia. We also observed similar benefits conferred by L-cit in a more aggressive 
model of DN in STZ-rats, which also showed reduced proteinuria after 8 weeks of treatment.

Diabetic urinary albumin leakage involves several mechanisms, including proximal tubular injury $(40,41)$ and disruption of the glomerular barrier (42). The relevance of the glomerular endothelium in the maintenance of barrier function has only been recently recognized (12). While endothelial NO generation contributes to endothelial glycocalyx and barrier preservation (11,43,44), an increase in the ROS/NO ratio causes disruption of the glycocalyx, resulting in enhanced albumin permeability $(45,46)$.

We have found a reduction in mitochondrial ROS generation, combined with a restoration of NO production in HGECs treated with L-cit before exposure to HG-supplemented medium. This effect may thus at least partially account for the reduced glomerular albumin leakage we have found in the diabetic animals supplemented with L-cit. In support of this is the reduced permeability to FITC-dextran of HGEC monolayers exposed to $\mathrm{HG}$ and concurrently treated with L-cit.

We did not assess either constitutive (endothelial and neuronal) or inducible NOS expression in the kidneys of our diabetic animals, because the three NOS isoforms have been described to be differentially altered in $\mathrm{DN}(47,48)$. Indeed, the discrepant results on NOS expression and NO involvement in diabetic pathology have been evaluated in other diabetic complications $(49,50)$.

Our current results, along with previous work, support the notion that bioavailability of NO is reduced in the diabetic vessels $(8,51,52)$. Therefore, adding L-cit to current therapies may lead to a safe and efficacious option to improve vascular diabetic complications. Moreover, due to the significant role of $\mathrm{NO}$ in the regulation of insulin release from pancreatic $\beta$-cells (53), L-cit may also be useful as a potential insulinotropic agent. However, the effect of $\mathrm{L}$-cit on pancreatic $\beta$-cell function requires further studies.

Several studies have also suggested a role for endothelial NO in suppressing fibrotic pathways in different organs and pathologies associated with diabetes and other diseases $(54,55)$. As such, the protective effect of L-cit on eNOS function may have led to the reduction in kidney fibrosis, as observed in our study in diabetic mice and rats after 16 and 8 weeks of diabetes, respectively.

The protective effects of L-cit toward UAE and kidney fibrosis were observed despite a sustained elevation of ArgII protein levels in the renal cortex. ArgII protein was significantly elevated in L-cit treated diabetic mice and rats over control and untreated diabetic animals at the end of the study, when protection on kidney pathology was more evident. Interestingly, the protective effects of L-cit administration in other pathologies have also been shown to be accompanied by an enhanced tissue expression of ArgII (23).

Our findings prompt the question about the role of ArgII for tubular function in diabetes. ArgII is present in the mitochondria of PT, as well as of inner medullary collecting ducts (17) and provides L-ornithine for the synthesis of polyamines (56). The cellular balance of polyamines is necessary for DNA stabilization and replication (57), as well as for the maintenance of PT integrity and function (58).

Damage of PT under the insult of HG levels, especially in patients with poor glycemic control (59), requires an extensive repair process, either by regeneration of de-differentiated surviving cells (60) or by proliferation and differentiation of stem cells (61). It has been recently demonstrated that spermidine enhances epithelial stem cell function (62). Thus, adequate polyamine levels may allow the PT to resume normal functions, and L-cit may facilitate this process by providing more L-arg for ArgII function.

In addition, up-regulation of mitochondrial ArgII in diabetic PT may represent a stress response to an increased energy demand in this actively reabsorptive segment of the nephron. Arginasederived ornithine in the mitochondria may be converted to Lglutamate that enters the tricarboxylic acid cycle as oxoglutarate (63). L-cit could as such provide precursors to maintain the energetic metabolism of PT via mitochondrial ArgII. Diabetic kidneys from L-cit-treated rats clearly showed a reduced number of positive tubules for KIM-1 expression, a marker of proximal tubular damage. This effect may also be associated with an improvement of proteinuria (64) observed in L-cit treated diabetic rats.

The results of our comparative studies between WT and ArgII knock out mice partially differ with a recent report by others (22). Despite a trend to reduced levels of albuminuria in diabetic ArgII knock out mice, the reduction was not significantly different from untreated WT diabetic mice. Differences between the Morris study and ours likely arise from the significantly greater age of our mice. Indeed, we observed a severe dilation and morphological alterations of cortical tubules, as well as greater BUN levels in ArgII knock out mice, as compared to untreated diabetic WT mice. These findings suggest that with advanced age, lack of ArgII may limit tubular repair and may accelerate the decay in glomerular filtration rate observed in the diabetic condition. Other reported mechanisms may also apply for tubular damage in ArgII knock out mice $(65,66)$. To that purpose, it would be interesting to determine in future studies, whether L-cit supplementation to ArgII knock out mice prevents diabetes-induced tubular damage and enhancement of BUN levels.

Intriguingly, collagen deposition in kidneys isolated from diabetic ArgII knock out mice was not different from the one observed in control WT mice. A limited availability of the precursor proline, provided by the ArgII/ornithine aminotransferase pathway, may be the cause of reduced renal collagen synthesis/crosslink in this group, which indicates that ArgII has an important contribution to renal collagen content. However, the cost-effect of specific ArgII inhibition in advanced stages of diabetic animal models remains to be investigated.

In addition to the previous findings, $\mathrm{L}$-cit treatment to diabetic mice prevented body wasting even in the absence of blood glycemic control. Type 1 diabetic patients under poor glycemic control, common in low income or un-insured patients in the United States or in under-developed countries (67) exhibit detrimentally low intracellular energy metabolism and significant weight loss, leading to chronic fatigue and general body weakness. L-Cit may protect against diabetic muscle wasting via nutritional support, providing the precursor for creatine synthesis $(68,69)$.

A substantial benefit conferred by L-cit supplementation is the significant elevation of the anti-inflammatory cytokine IL-10. It has been recently recognized that common inflammatory factors play a role in both type 1 and 2 diabetic pathology $(30,70)$, which has important therapeutic implications (71-73). IL-10 has 
been shown to selectively induce ArgII expression in macrophages (74) and to also attenuate a pro-inflammatory cytokine expression and iNOS-derived NO production in human and mouse monocyte/macrophage cells in the presence of apoptotic cells (75). Apoptosis of PT epithelial cells is a feature of the hyperglycemic insult in DN, and activated PT epithelial cells, as an alternative to macrophages, are able to phagocytose neighboring apoptotic cells (76). Moreover, PT epithelial cells play an important role in antiinflammatory mechanisms within the tubulointerstitium during renal injuries $(77,78)$ and are capable of generating their own production of IL-10 (33).

Although we did not measure local kidney tissue or urinary levels of IL-10 in our study, but rather in plasma, it is nevertheless likely that both local and systemic anti-inflammatory mechanisms may take place under the setting of L-cit supplementation, since this treatment was accompanied by enhanced ArgII expression in PT, and by increased plasma levels of IL-10. In support of our findings in vivo, we observed that huPTECs cultured under HG-supplemented medium in the presence of L-cit for 1 week, produced significantly enhanced levels of the anti-inflammatory cytokine IL-10, as compared to cells treated with HG alone. This is a prominent feature of $\mathrm{L}$-cit's actions on huPTEC, which may be of high significance in the context of current clinical trials aimed to limit inflammation in diabetic patients, and to reduce progression of DN toward ESRD. In correspondence with our observations that L-cit increases IL-10 generation, it has been recently shown that Citrullus lanatus (Watermelon), a rich source of L-cit, was beneficial in a murine inflammatory disease model, by means of increasing plasma levels of IL-10 (79).

The enhanced production of the anti-inflammatory cytokine IL-10 by $\mathrm{L}$-cit in HG-treated huPTEC was accompanied by a reduction of levels of the pro-inflammatory cytokines IL-12 (p70) and IL- $1 \beta$ both of which were induced above basal levels by HG in cells not treated with $\mathrm{L}$-cit. In vivo, these pro-inflammatory cytokines may establish the settings for a crosstalk between tubular cells and surrounding infiltrating leukocytes, to amplify the inflammatory milieu of diabetic kidneys. As such, L-cit-induced IL-10 generation may be important in limiting inflammation in the kidney.

In accordance with our findings on ArgII expression in kidneys of mice at late stages of diabetes, cultured huPTEC under HG condition had a reduced expression of ArgII protein levels. L-Cit significantly enhanced ArgII in HG-treated huPTEC, an effect that was reduced by co-administration of IL-10 neutralizing antibody with L-cit. These results indicate that up-regulation of ArgII in PT is a marker of the anti-inflammatory actions of IL-10 on renal tubules.

We could detect an increased level of nuclear localization of the executioner caspase 6, a mediator of apoptosis, in huPTEC exposed to $\mathrm{HG}$ levels. $\mathrm{L}$-Cit blunted this effect of $\mathrm{HG}$ at least partially in an IL-10-dependent manner. This indicates that the observed caspase 6 activation was linked to a pro-inflammatory cytokine, the generation of which was inhibited by IL-10. Although more research is needed to unravel what cytokines are responsible for the caspase 6 activation in HG-treated huPTEC, an interesting candidate could be IL-1, which was shown to be increased by HG in huPTEC in our experiments and whose generation was blunted by L-cit. IL-1 was shown to induce Fas ligand generation, a potent inducer of apoptosis in renal tubular cells (80).

In conclusion, our study demonstrates that L-cit supplementation is protective to the nephron function. L-Cit not only reduces UAE and prevents collagen deposits in the kidneys of diabetic animals, but also establishes the settings for an antiinflammatory response in the $\mathrm{PT}$, with the potential to direct the immune response toward an anti-inflammatory profile in monocyte/macrophages as well. These observations are substantiated by the elevation of tubular ArgII expression, and of plasma levels of IL-10.

It remains to be established whether L-cit sustains tubular mitochondrial function, by providing precursors via ArgII and whether this effect is linked to repair processes of the proximal nephron under the hyperglycemic insult. As such, this work lays the foundation for a broader investigation of the effects of L-cit supplementation on local vs. systemic IL-10 generation, which may have important therapeutic applicability in diabetic patients.

\section{ACKNOWLEDGMENTS}

We thank the many excellent contributions of Ms. Jennifer Iddings and Ms. Su Matragoon to part of these studies. This work was supported by the Juvenile Diabetes Research Foundation (Innovative grant 5-2009-468 to Maritza J. Romero), the National Institutes of Health National Heart, Lung, and Blood Institute (R01 HL70215 to Robert W. Caldwell and R01 HL104126 to Zsolt Bagi) and the National Institute of Diabetes and Digestive and Kidney Diseases (R24 DK094765 to Rudolf Lucas and Robert W. Caldwell).

\section{REFERENCES}

1. Weiner DE, Krassilnikova M, Tighiouart H, Salem DN, Levey AS, Sarnak MJ. CKD classification based on estimated GFR over three years and subsequent cardiac and mortality outcomes: a cohort study. BMC Nephrol (2009) 10:26. doi:10.1186/1471-2369-10-26

2. Böger RH. L-arginine therapy in cardiovascular pathologies: beneficial or dangerous? Curr Opin Clin Nutr Metab Care (2008) 11:55-61. doi:10.1097/MCO. 0b013e3282f2b0c3

3. Schulman SP, Becker LC, Kass DA, Champion HC, Terrin ML, Forman S, et al. L-arginine therapy in acute myocardial infarction: the vascular interaction with age in myocardial infarction (VINTAGE MI) randomized clinical trial. JAMA (2006) 295:58-64. doi:10.1001/jama.295.1.58

4. Smith HA, Canter JA, Christian KG, Drinkwater DC, Scholl FG, Christman BW, et al. Nitric oxide precursors and congenital heart surgery: a randomized controlled trial of oral citrulline. J Thorac Cardiovasc Surg (2006) 132:58-65. doi:10.1016/j.jtcvs.2006.02.012

5. Schwedhelm E, Maas R, Freese R, Jung D, Lukacs Z, Jambrecina A, et al. Pharmacokinetic and pharmacodynamic properties of oral L-citrulline and L-arginine: impact on nitric oxide metabolism. Br J Clin Pharmacol (2008) 65:51-9. doi:10.1111/j.1365-2125.2007.02990.x

6. Romero MJ, Platt D, Caldwell RB, Caldwell RW. Therapeutic use of citrulline in cardiovascular disease. Cardiovasc Drug Rev (2006) 24:275-90. doi:10.1111/ j.1527-3466.2006.00275.x

7. Shearer JD, Richards JR, Mills CD, Caldwell MD. Differential regulation of macrophage arginine metabolism: a proposed role in wound healing. Am J Physiol (1997) 272:E181-90.

8. Romero MJ, Platt DH, Tawfik HE, Labazi M, El-Remessy AB, Bartoli M, et al. Diabetes-induced coronary vascular dysfunction involves increased arginase activity. Circ Res (2008) 102:95-102. doi:10.1161/CIRCRESAHA.107.155028

9. Beleznai T, Feher A, Spielvogel D, Lansman SL, Bagi Z. Arginase 1 contributes to diminished coronary arteriolar dilation in patients with diabetes. Am J Physiol Heart Circ Physiol (2011) 300:H777-83. doi:10.1152/ajpheart.00831.2010 
10. Romero MJ, Iddings JA, Platt DH, Ali MI, Cederbaum SD, Stepp DW, et al. Diabetes-induced vascular dysfunction involves arginase I. Am J Physiol Heart Circ Physiol (2012) 302:H159-66. doi:10.1152/ajpheart.00774.2011

11. Predescu D, Predescu S, Shimizu J, Miyawaki-Shimizu K, Malik AB. Constitutive eNOS-derived nitric oxide is a determinant of endothelial junctional integrity. Am J Physiol Lung Cell Mol Physiol (2005) 289:L371-81. doi:10.1152/ajplung.00175.2004

12. Singh A, Fridén V, Dasgupta I, Foster RR, Welsh GI, Tooke JE, et al. High glucose causes dysfunction of the human glomerular endothelial glycocalyx. Am J Physiol Renal Physiol (2011) 300:F40-8. doi:10.1152/ajprenal.00103.2010

13. Kern RM, Yang Z, Kim PS, Grody WW, Iyer RK, Cederbaum SD. Arginase induction by sodium phenylbutyrate in mouse tissues and human cell lines. Mol Genet Metab (2007) 90:37-41. doi:10.1016/j.ymgme.2006.07.002

14. Levillain O, Balvay S, Peyrol S. Mitochondrial expression of arginase II in male and female rat inner medullary collecting ducts. J Histochem Cytochem (2005) 53:533-41. doi:10.1369/jhc.4A6489.2005

15. Levillain O, Rabier D, Duclos B, Gaudreau P, Vinay P. L-arginine metabolism in dog kidney and isolated nephron segments. Metabolism (2008) 57:9-23. doi:10.1016/j.metabol.2007.06.001

16. Sands JM, Blount MA, Klein JD. Regulation of renal urea transport by vasopressin. Trans Am Clin Climatol Assoc (2011) 122:82-92.

17. Levillain O, Hus-Citharel A, Morel F, Bankir L. Localization of urea and ornithine production along mouse and rabbit nephrons: functional significance. Am J Physiol (1992) 263:F878-85.

18. Durante W, Liao L, Reyna SV, Peyton KJ, Schafer AI. Physiological cyclic stretch directs L-arginine transport and metabolism to collagen synthesis in vascular smooth muscle. FASEB J (2000) 14:1775-83. doi:10.1096/fj.99-0960com

19. Thomson SC, Deng A, Bao D, Satriano J, Blantz RC, Vallon V. Ornithine decarboxylase, kidney size, and the tubular hypothesis of glomerular hyperfiltration in experimental diabetes. J Clin Invest (2001) 107:217-24. doi:10.1172/ JCI10963

20. Zahedi K, Bissler JJ, Wang Z, Josyula A, Lu L, Diegelman P, et al. Spermidine/spermine N1-acetyltransferase overexpression in kidney epithelial cells disrupts polyamine homeostasis, leads to DNA damage, and causes G2 arrest. Am J Physiol Cell Physiol (2007) 292:C1204-15. doi:10.1152/ajpcell. 00451.2006

21. Phang JM, Liu W, Zabirnyk O. Proline metabolism and microenvironmental stress. Annu Rev Nutr (2010) 30:441-63. doi:10.1146/annurev.nutr.012809. 104638

22. Morris SM Jr, Gao T, Cooper TK, Kepka-Lenhart D, Awad AS. Arginase-2 mediates diabetic renal injury. Diabetes (2011) 60:3015-22. doi:10.2337/db11-0901

23. Vadivel A, Aschner JL, Rey-Parra GJ, Magarik J, Zeng H, Summar M, et al. Lcitrulline attenuates arrested alveolar growth and pulmonary hypertension in oxygen-induced lung injury in newborn rats. Pediatr Res (2010) 68:519-25. doi:10.1203/PDR.0b013e3181f90278

24. Deignan JL, Livesay JC, Yoo PK, Goodman SI, O’Brien WE, Iyer RK, et al. Ornithine deficiency in the arginase double knockout mouse. Mol Genet Metab (2006) 89:87-96. doi:10.1016/j.ymgme.2006.04.007

25. Shi O, Morris SM Jr, Zoghbi H, Porter CW, O’Brien WE. Generation of a mouse model for arginase II deficiency by targeted disruption of the arginase II gene. Mol Cell Biol (2001) 21:811-3. doi:10.1128/MCB.21.3.811-813.2001

26. Lucas R, Sridhar S, Rick FG, Gorshkov B, Umapathy NS, Yang G, et al. Agonist of growth hormone-releasing hormone reduces pneumolysin-induced pulmonary permeability edema. Proc Natl Acad Sci U S A (2012) 109:2084-9. doi:10.1073/pnas.1121075109

27. Hadi AM, Mouchaers KT, Schalij I, Grunberg K, Meijer GA, Vonk-Noordegraaf A, et al. Rapid quantification of myocardial fibrosis: a new macro-based automated analysis. Cell Oncol (Dordr) (2011) 34:343-54. doi:10.1007/s13402-0110035-7

28. Corraliza IM, Campo ML, Soler G, Modolell M. Determination of arginase activity in macrophages: a micromethod. J Immunol Methods (1994) 174:231-5. doi:10.1016/0022-1759(94)90027-2

29. Lucas R, Parikh SJ, Sridhar S, Guo DH, Bhagatwala J, Dong Y, et al. Cytokine profiling of young overweight and obese female African American adults with prediabetes. Cytokine (2013) 64:310-5. doi:10.1016/j.cyto.2013.05.025

30. Odegaard JI, Chawla A. Connecting type 1 and type 2 diabetes through innate immunity. Cold Spring Harb Perspect Med (2012) 2:a007724. doi:10.1101/ cshperspect.a007724
31. Kim SS, Song SH, Kim IJ, Yang JY, Lee JG, Kwak IS, et al. Clinical implication of urinary tubular markers in the early stage of nephropathy with type 2 diabetic patients. Diabetes Res Clin Pract (2012) 97:251-7. doi:10.1016/j.diabres.2012. 02.019

32. Alter ML, Kretschmer A, Von Websky K, Tsuprykov O, Reichetzeder C, Simon A, et al. Early urinary and plasma biomarkers for experimental diabetic nephropathy. Clin Lab (2012) 58:659-71.

33. Dhande I, Ali Q, Hussain T. Proximal tubule angiotensin AT2 receptors mediate an anti-inflammatory response via interleukin-10: role in renoprotection in obese rats. Hypertension (2013) 61:1218-26. doi:10.1161/ HYPERTENSIONAHA.111.00422

34. Singh AB, Kaushal V, Megiyesi JK, Shah SV, Kaushal GP. Cloning and expression of rat caspase- 6 and its localization in renal ischemia/reperfusion injury. Kidney Int (2002) 62:106-15. doi:10.1046/j.1523-1755.2002.00427.x

35. Kawano H, Motoyama T, Hirashima O, Hirai N, Miyao Y, Sakamoto T, et al. Hyperglycemia rapidly suppresses flow-mediated endothelium-dependent vasodilation of brachial artery. J Am Coll Cardiol (1999) 34:146-54. doi:10.1016/ S0735-1097(99)00168-0

36. Bagi Z, Koller A, Kaley G. Superoxide-NO interaction decreases flow- and agonist-induced dilations of coronary arterioles in type 2 diabetes mellitus. Am J Physiol Heart Circ Physiol (2003) 285:H1404-10. doi:10.1152/ajpheart.00235. 2003

37. Pham MN, Kolb H, Battelino T, Ludvigsson J, Pozzilli P, Zivehe F, et al. Fasting and meal-stimulated residual beta cell function is positively associated with serum concentrations of proinflammatory cytokines and negatively associated with anti-inflammatory and regulatory cytokines in patients with longer term type 1 diabetes. Diabetologia (2013) 56:1356-63. doi:10.1007/s00125-0132883-3

38. Mochida T, Tanaka T, Shiraki Y, Tajiri H, Matsumoto S, Shimbo K, et al. Timedependent changes in the plasma amino acid concentration in diabetes mellitus. Mol Genet Metab (2011) 103:406-9. doi:10.1016/j.ymgme.2011.05.002

39. Sourij H, Meinitzer A, Pilz S, Grammer TB, Winkelmann BR, Boehm BO, et al. Arginine bioavailability ratios are associated with cardiovascular mortality in patients referred to coronary angiography. Atherosclerosis (2011) 218:220-5 doi:10.1016/j.atherosclerosis.2011.04.041

40. Thomas MC, Burns WC, Cooper ME. Tubular changes in early diabetic nephropathy. Adv Chronic Kidney Dis (2005) 12:177-86. doi:10.1053/j.ackd. 2005.01.008

41. Russo LM, Sandoval RM, Campos SB, Molitoris BA, Comper WD, Brown D. Impaired tubular uptake explains albuminuria in early diabetic nephropathy. J Am Soc Nephrol (2009) 20:489-94. doi:10.1681/ASN.2008050503

42. Pugliese G, Ricci C, Iacobini C, Menini S, Fioretto P, Ferrandi M, et al. Glomerular barrier dysfunction in glomerulosclerosis-resistant Milan rats with experimental diabetes: the role of renal haemodynamics. J Pathol (2007) 213:210-8. doi:10.1002/path.2226

43. Becker BF, Chappell D, Bruegger D, Annecke T, Jacob M. Therapeutic strategies targeting the endothelial glycocalyx: acute deficits, but great potential. Cardiovasc Res (2010) 87:300-10. doi:10.1093/cvr/cvq137

44. Lucas R, Yang G, Gorshkov BA, Zemskov EA, Sridhar S, Umapathy NS, et al. Protein kinase $\mathrm{C}-\alpha$ and arginase I mediate pneumolysin-induced pulmonary endothelial hyperpermeability. Am J Respir Cell Mol Biol (2012) 47:445-53. doi:10.1165/rcmb.2011-0332OC

45. Kuwabara A, Satoh M, Tomita N, Sasaki T, Kashihara N. Deterioration of glomerular endothelial surface layer induced by oxidative stress is implicated in altered permeability of macromolecules in Zucker fatty rats. Diabetologia (2010) 53:2056-65. doi:10.1007/s00125-010-1810-0

46. Shenouda SM, Widlansky ME, Chen K, Xu G, Holbrook M, Tabit CE, et al. Altered mitochondrial dynamics contributes to endothelial dysfunction in diabetes mellitus. Circulation (2011) 124:444-53. doi:10.1161/ CIRCULATIONAHA.110.014506

47. Komers R, Anderson S. Paradoxes of nitric oxide in the diabetic kidney. Am J Physiol Renal Physiol (2003) 284:F1121-37. doi:10.1152/ajprenal.00265.2002

48. Schrijvers BF, De Vriese AS, Flyvbjerg A. From hyperglycemia to diabetic kidney disease: the role of metabolic, hemodynamic, intracellular factors and growth factors/cytokines. Endocr Rev (2004) 25:971-1010. doi:10.1210/er.2003-0018

49. Hattenbach LO, Allers A, Klais C, Koch F, Hecker M. L-arginine-nitric oxide pathway-related metabolites in the aqueous humor of diabetic patients. Invest Ophthalmol Vis Sci (2000) 41:213-7. 
50. Drago F, Bucolo C. Therapeutic potential of nitric oxide modulation in ocular diseases. Drug News Perspect (2010) 23:430-7. doi:10.1358/dnp.2010.23.7. 1484488

51. Hink U, Li H, Mollnau H, Oelze M, Matheis E, Hartmann M, et al. Mechanisms underlying endothelial dysfunction in diabetes mellitus. Circ Res (2001) 88:E14-22. doi:10.1161/01.RES.88.2.e14

52. Santilli F, Cipollone F, Mezzetti A, Chiarelli F. The role of nitric oxide in the development of diabetic angiopathy. Horm Metab Res (2004) 36:319-35. doi:10.1055/s-2004-814489

53. Smukler SR, Tang L, Wheeler MB, Salapatek AM. Exogenous nitric oxide and endogenous glucose-stimulated beta-cell nitric oxide augment insulin release. Diabetes (2002) 51:3450-60. doi:10.2337/diabetes.51.12.3450

54. Placier S, Boffa JJ, Dussaule JC, Chatziantoniou C. Reversal of renal lesions following interruption of nitric oxide synthesis inhibition in transgenic mice. Nephrol Dial Transplant (2006) 21:881-8. doi:10.1093/ndt/gfk004

55. Kanetsuna Y, Takahashi K, Nagata M, Gannon MA, Breyer MD, Harris RC, et al. Deficiency of endothelial nitric-oxide synthase confers susceptibility to diabetic nephropathy in nephropathy-resistant inbred mice. Am J Pathol (2007) 170:1473-84. doi:10.2353/ajpath.2007.060481

56. Schipper RG, Verhofstad AA. Distribution patterns of ornithine decarboxylase in cells and tissues: facts, problems, and postulates. J Histochem Cytochem (2002) 50:1143-60. doi:10.1177/002215540205000901

57. Alm K, Oredssib S. Cells and polyamines do it cyclically. Essays Biochem (2009) 4:63-76. doi:10.1042/bse0460005

58. Levillain O, Hus-Citharel A, Garvi S, Peyrol S, Reymond I, Mutin M, et al. Ornithine metabolism in male and female rat kidney: mitochondrial expression of ornithine aminotransferase and arginase II. Am J Physiol Renal Physiol (2004) 286:F727-38. doi:10.1152/ajprenal.00315.2003

59. Kumar D, Robertson S, Burns KD. Evidence of apoptosis in human diabetic kidney. Mol Cell Biochem (2004) 259:67-70. doi:10.1023/B:MCBI.0000021346. $03260.7 \mathrm{e}$

60. Zhang Z, Xing J, Ma L, Gong R, Chin YE, Zhuang S. Transglutaminase-1 regulates renal epithelial cell proliferation through activation of Stat-3. J Biol Chem (2009) 284:3345-53. doi:10.1074/jbc.M808396200

61. Lindgren D, Boström AK, Nilsson K, Hansson J, Sjölund J, Möller C, et al. Isolation and characterization of progenitor-like cells from human renal proximal tubules. Am J Pathol (2011) 178:828-37. doi:10.1016/j.ajpath.2010.10.026

62. Ramot Y, Tiede S, Bíró T, Abu Bakar MH, Sugawara K, Philpott MP, et al. Spermidine promotes human hair growth and is a novel modulator of human epithelial stem cell functions. PLoS One (2011) 6:e22564. doi:10.1371/journal.pone. 0022564

63. Smith AC, Robinson AJ. A metabolic model of the mitochondrion and its use in modelling diseases of the tricarboxylic acid cycle. BMC Syst Biol (2011) 29:102. doi:10.1186/1752-0509-5-102

64. Waanders F, Vaidya VS, van Goor H, Leuvenink H, Damman K, Hamming I, et al. Effect of renin-angiotensin-aldosterone system inhibition, dietary sodium restriction, and/or diuretics on urinary kidney injury molecule 1 excretion in nondiabetic proteinuric kidney disease: a post hoc analysis of a randomized controlled trial. Am J Kidney Dis (2009) 53:16-25. doi:10.1053/j.ajkd.2008. 07.021

65. Huynh NN, Andrews KL, Head GA, Khong SM, Mayorov DN, Murphy AJ, et al. Arginase II knockout mouse displays a hypertensive phenotype despite a decreased vasoconstrictory profile. Hypertension (2009) 54:294-301. doi:10. 1161/HYPERTENSIONAHA.108.121731

66. Marini JC, Keller B, Didelija IC, Castillo L, Lee B. Enteral arginase II provides ornithine for citrulline synthesis. Am J Physiol Endocrinol Metab (2011) 300:E188-94. doi:10.1152/ajpendo.00413.2010

67. Seligman HK, Jacobs EA, López A, Tschann J, Fernandez A. Food insecurity and glycemic control among low-income patients with type 2 diabetes. Diabetes Care (2012) 35:233-8. doi:10.2337/dc11-1627

68. Haines RJ, Pendleton LC, Eichler DC. Argininosuccinate synthase: at the center of arginine metabolism. Int J Biochem Mol Biol (2011) 2:8-23.
69. Gualano B, De Salles Painneli V, Roschel H, Artioli GG, Neves M Jr, De Sá Pinto AL, et al. Creatine in type 2 diabetes: a randomized, double-blind, placebo-controlled trial. Med Sci Sports Exerc (2011) 43:770-8. doi:10.1249/ MSS.0b013e3181fcee7d

70. Graves DT, Naguib G, Lu H, Leone C, Hsue H, Krall E. Inflammation is more persistent in type 1 diabetic mice. J Dent Res (2005) 84:324-8. doi:10.1177/ 154405910508400406

71. Moon RJ, Bascombe LA, Holt RI. The addition of metformin in type 1 diabetes improves insulin sensitivity, diabetic control, body composition and patient well-being. Diabetes Obes Metab (2007) 9:143-5. doi:10.1111/j.1463-1326.2006. 00599.x

72. Zheng D, Wang Y, Cao Q, Lee VW, Zheng G, Sun Y, et al. Transfused macrophages ameliorate pancreatic and renal injury in murine diabetes mellitus. Nephron Exp Nephrol (2011) 118:e87-99. doi:10.1159/000321034

73. Parsa R, Andresen P, Gillett A, Mia S, Zhang XM, Mayans S, et al. Adoptive transfer of immunomodulatory M2 macrophages prevents type 1 diabetes in NOD mice. Diabetes (2012) 61:2881-92. doi:10.2337/db11-1635

74. Barksdale AR, Bernard AC, Maley ME, Gellin GL, Kearney PA, Boulanger BR, et al. Regulation of arginase expression by T-helper II cytokines and isoproterenol. Surgery (2004) 135:527-35. doi:10.1016/j.surg.2003.10.007

75. Johann AM, Barra V, Kuhn AM, Weigert A, von Knethen A, Brüne B. Apoptotic cells induce arginase II in macrophages, thereby attenuating NO production. FASEB J (2007) 21:2704-12. doi:10.1096/fj.06-7815com

76. Ichimura T, Asseldonk EJ, Humphreys BD, Gunaratnam L, Duffield JS, Bonventre JV. Kidney injury molecule-1 is a phosphatidylserine receptor that confers a phagocytic phenotype on epithelial cells. J Clin Invest (2008) 118:1657-68. doi:10.1172/JCI34487

77. Kassianos AJ, Sampangi S, Wang X, Roper KE, Beagley K, Healy H, et al. Human proximal tubule epithelial cells modulate autologous dendritic cell function. Nephrol Dial Transplant (2013) 28:303-12. doi:10.1093/ndt/gfs136

78. Kronsteiner B, Peterbauer-Scherb A, Grillari-Voglauer R, Redl H, Gabriel C, van Griensven $\mathrm{M}$, et al. Human mesenchymal stem cells and renal tubular epithelial cells differentially influence monocyte-derived dendritic cell differentiation and maturation. Cell Immunol (2011) 267:30-8. doi:10.1016/j.cellimm. 2010.11.001

79. Poduri A, Rateri DL, Saha SK, Saha S, Daugherty A. Citrullus lanatus "sentinel" (watermelon) extract reduces atherosclerosis in LDL receptor-deficient mice. J Nutr Biochem (2012) 24:882-6. doi:10.1016/j.jnutbio.2012.05.011

80. Schelling JR, Cleveland RP. Involvement of Fas-dependent apoptosis in renal tubular epithelial cell deletion in chronic renal failure. Kidney Int (1999) 56:1313-6. doi:10.1046/j.1523-1755.1999.00684.x

Conflict of Interest Statement: The authors declare that the research was conducted in the absence of any commercial or financial relationships that could be construed as a potential conflict of interest.

Received: 13 May 2013; accepted: 09 December 2013; published online: 24 December 2013.

Citation: Romero MJ, Yao L, Sridhar S, Bhatta A, Dou H, Ramesh G, Brands MW, Pollock DM, Caldwell RB, Cederbaum SD, Head CA, Bagi Z, Lucas R and Caldwell $R W(2013)$ L-citrulline protects from kidney damage in type 1 diabetic mice. Front. Immunol. 4:480. doi:10.3389/fimmu.2013.00480

This article was submitted to Inflammation, a section of the journal Frontiers in Immunology.

Copyright (c) 2013 Romero, Yao, Sridhar, Bhatta, Dou, Ramesh, Brands, Pollock, Caldwell, Cederbaum, Head, Bagi, Lucas and Caldwell. This is an open-access article distributed under the terms of the Creative Commons Attribution License (CC BY). The use, distribution or reproduction in other forums is permitted, provided the original author(s) or licensor are credited and that the original publication in this journal is cited, in accordance with accepted academic practice. No use, distribution or reproduction is permitted which does not comply with these terms. 